
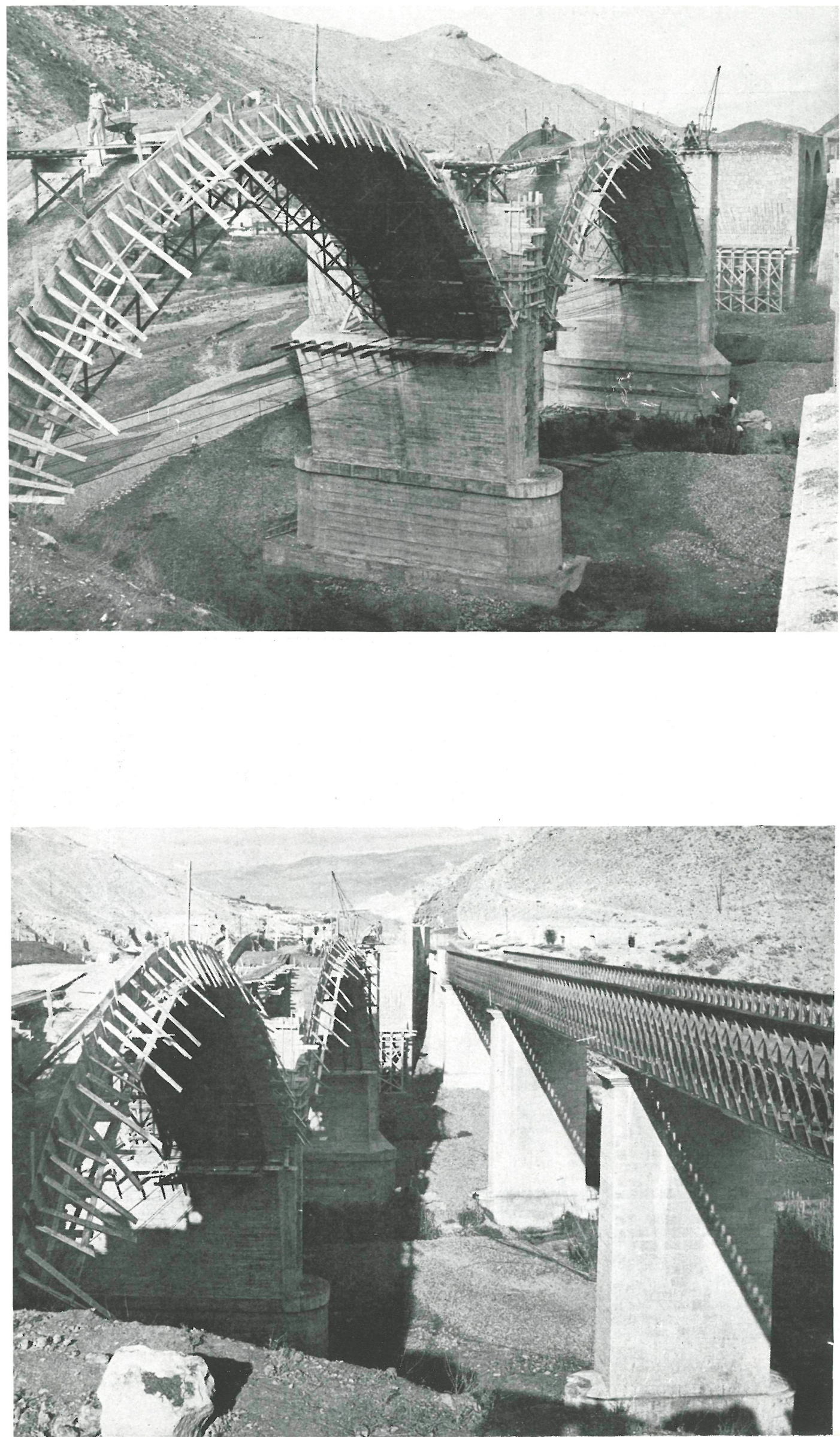

$562-36$

\section{puente sobre el río Andarax}

El aumento continuo que está experimentando actualmente en España el tráfico por carretera, crea problemas de distinta naturaleza, que se refieren unos, al ensanchamiento y mejora de las calzadas; otros, a la visibilidad, pendientes, curvas, etc., y, como consecuencia de ello, la reforma y nuevas construcciones de obras de fábrica.

Un ejemplo de este tipo de modificación se ha presentado en la carretera de Almería a Granada, donde se construye, sobre el río Andarax, un nuevo puente entre Alabia y Alhama.

Al antiguo puente de viga recta en celosía metálica sustituye el nuevo, de hormigón armado, con tres tramos centrales en arco. El carácter torrencial del río ha obligado a prever un paso suficientemente amplio para el desagüe de las grandes avenidas. Pilas y estribos adquieren el volumen y rigidez conveniente para hacer frente a toda acción erosiva de las rápidas y torrenciales aguas del río.

Fotos: M. GARCIA MOYA 